\title{
The Distribution of Lead in Milk and the Fate of Milk Lead in the Gastrointestinal Tract of Suckling Rats
}

\author{
JASON R. BEACH AND SUSAN J. HENNING \\ Department of Biology, University of Houston, Houston, Texas 77004
}

\begin{abstract}
Milk can be a significant source of lead (Pb) for young mammals, including humans. Certain essential trace elements have previously been shown to be specifically associated with particular milk components and such associations often increase bioavailability. Thus, the first goal of this study was to determine the distribution of $\mathrm{Pb}$ in cream, casein, and whey fractions of various milks under various conditions using ${ }^{203} \mathrm{~Pb}$ as a tracer. In rat milk almost $90 \%$ of the $\mathrm{Pb}$ was found to be associated with the casein micelles, regardless of: 1) whether the milk was labeled in vivo or in vitro; b) whether the milk was fresh or frozen; and c) the added concentration of $\mathrm{Pb}$ (over the range 0.01-75 $\mu \mathrm{g} / \mathrm{ml}$ ). The remainder of the $\mathrm{Pb}$ was approximately equally distributed between cream and whey. A virtually identical pattern of $\mathrm{Pb}$ distribution was $\mathrm{ob}$ served with bovine milk. $\mathrm{Pb}$ added to infant formula also associated predominantly with casein micelles, although the $\mathrm{Pb}$ content of this fraction was significantly less than with rat and bovine milks. The second goal of the study was to determine if $\mathrm{Pb}$ remained associated with casein as it traversed the gastrointestinal tract of infant rats. For this purpose, rat pups aged 15-16 days were gavaged with ${ }^{203} \mathrm{~Pb}$-labeled rat milk, and lumenal contents from the stomach and small intestine were collected $2 \mathrm{~h}$ later. Differential centrifugation of the homogenized lumenal contents showed that in the stomach the $\mathrm{Pb}$ was associated primarily with the casein curd. By the time chyme reached the distal small intestine, $\mathrm{Pb}$ was found predominantly in a fraction that was not precipitable by high-speed centrifugation (thus, not intact casein micelles), but was nondialyzable. We conclude that $\mathrm{Pb}$ in milk is protein bound and remains this way as it traverses the stomach and proximal small intestine of the infant rat. (Pediatr Res 23: $58-62,1988)$.
\end{abstract}

\section{Abbreviations}

$\mathrm{Pb}$, lead

The deleterious effects of both symptomatic and asymptomatic $\mathrm{Pb}$ poisoning are well documented for infants of humans and experimental animals (1-7). This high risk group demonstrates a greater intestinal absorption of $\mathrm{Pb}$ than do adults (8-11) and as a result may be more susceptible to even modest levels of environmental pollution. There is evidence in rodents that en-

Received April 22, 1987; accepted September 1, 1987.

Correspondence Dr. S. J. Henning, Department of Biology, University of Houston, Houston, TX 77004

Supported by Grants HD-14094 and RR-17147 from the National Institutes of Health. hanced absorption of $\mathrm{Pb}$ during infancy is due in part to the milk diet $(12,13)$ and in part to the immaturity of the digestive tract (11,14-16). Of several environmental predictors examined in human infants, milk $\mathrm{Pb}$ was the strongest correlate of 6-month blood $\mathrm{Pb}$ (17). Total $\mathrm{Pb}$ content has been reported for a variety of milks (18-23), but the association of $\mathrm{Pb}$ with various milk components has not previously been investigated. Thus, our first goal was to determine the distribution of $\mathrm{Pb}$ in various milk fractions in order to assess whether there are specific associations that might enhance bioavailability, as is known to occur for several essential trace elements (24-31).

Both humans and experimental animals display reduced gastric proteolysis during infancy (32-34). If $\mathrm{Pb}$ is bound to milk proteins, it may remain in a bound form as chyme passes into the small intestine. During the suckling period, significant amounts of intact protein are absorbed by both humans and rodents (34). Such a mechanism could account in part for the enhanced absorption of $\mathrm{Pb}$ during infancy. Thus, our second goal was to determine the chemical form of $\mathrm{Pb}$ in the gastrointestinal tract of infant rats following gavage with milk containing $\mathrm{Pb}$.

\section{MATERIALS AND METHODS}

Chemicals. Synthetic oxytocin (grade III), ammonium sulfate, and sodium acetate were obtained from Sigma Chemical Co. (St. Louis, MO). Nonlabeled lead acetate and lead chloride were from Matheson, Coleman and Bell (Cincinnati, $\mathrm{OH}$ ) and Mallenckrodt (St. Louis, MO), respectively. ${ }^{203} \mathrm{PbCl}_{2}$ was from New England Nuclear Corp. (Boston, MA). Specific activity varied with shipment, ranging from 13.4 to $134.0 \mu \mathrm{Ci} / \mu \mathrm{g}$.

Animals. Timed-pregnant rats of the Sprague-Dawley strain [Charles River $\mathrm{Crl}: \mathrm{CD}(\mathrm{SD}) \mathrm{BR}$ ] were obtained from Charles River Laboratories, Inc., Wilmington, MA. They were housed individually in opaque polystyrene cages with chrome-plated wire tops. Animal quarters were maintained at a temperature of $21 \pm 1^{\circ} \mathrm{C}$ and a $12 \mathrm{~h}$ light/dark cycle. All animals were provided with Rodent Laboratory Chow 5001 (Ralston Purina, St. Louis, $\mathrm{MO}$ ) and water ad libitum. On the due date, the vivarium was checked approximately every $2 \mathrm{~h}$ for births. The date of birth was designated as day 0 . Litters were culled to eight or nine pups of similar size at approximately $24 \mathrm{~h}$ postpartum.

Quantitation of data. The ${ }^{203} \mathrm{~Pb}$ content of all samples was determined by counting in a Packard Multi-Prias Auto-Gamma Counting System, Downers Grove, IL. The exact time was recorded for each sample counted, and cpm values were corrected for decay using the half-life value of $52.1 \mathrm{~h}$.

Milk samples. Rat milk was obtained from dams that had been isolated from their pups for $12 \mathrm{~h}$ to allow mammary accumulation. Milk was expressed manually under ether anesthesia, following intraperitoneal injection with oxytocin (1 unit). Dams were milked only once, because Keen et al. (35) demon- 
strated that serial milking affects the distribution of some nutritional metals in rat milk. Four fresh, raw bovine milk samples were obtained from local dairies and were kept at $4^{\circ} \mathrm{C}$ until used. A commercially available milk-based brand of infant formula $(60 / 40)$ was purchased as the canned liquid concentrate and prepared according to the manufacturer's directions.

Fractionation of milk. Each milk sample was fractionated in duplicate according to the scheme described by Loh and Kaldor (36) for rat milk. Briefly, this involves a 10-min low-speed centrifugation $\left(1700 \times g \mathrm{r}_{\max }\right)$ which separates whole milk into cream and skim milk. The latter is then subjected to 45 min of high-speed centrifugation $\left(72,000 \times g\right.$ at $\left.r_{\max }\right)$ which separates whey (supernatant) from casein micelles (pellet). The total ${ }^{203} \mathrm{~Pb}$ content in each fraction was computed and expressed as a percentage of that in the whole milk.

Study 1. The aim of this study was to examine the distribution of ${ }^{203} \mathrm{~Pb}$ in milk. In the first experiment, rat milk was labeled in vivo by intraperitoneal injection of lactating dams (11 days postpartum) with $0.3 \mathrm{ml}$ of ${ }^{203} \mathrm{PbCl}_{2}(45 \mu \mathrm{Ci}, 2 \mu \mathrm{g} \mathrm{Pb})$ in 150 $\mathrm{mM}$ sodium acetate, $\mathrm{pH} 4.0$. This was calculated to be a trace dose which would not significantly elevate total $\mathrm{Pb}$ blood levels in the dam. After injection, dams were returned to their pups for $4 \mathrm{~h}$ to ensure continued milk production. Subsequently, dams and pups were separated for $12 \mathrm{~h}$ to allow milk to accumulate. Milk was collected as described above, cooled to $2-4^{\circ} \mathrm{C}$, and then fractionated to determine the distribution of $\mathrm{Pb}$.

Because in vivo labeling uses large amounts of isotope, the second experiment was designed to investigate the feasibility of in vitro labeling rat milk with ${ }^{203} \mathrm{~Pb}$. Rat milk was collected (at 11-17 days postpartum) and was used either immediately (fresh) or after storage for $1 \mathrm{wk}$ at $-15^{\circ} \mathrm{C}$ (frozen). In each case, $1-\mathrm{ml}$ samples of milk were incubated with $40 \mu \mathrm{l}$ of ${ }^{203} \mathrm{PbCl}_{2}(0.09 \mu \mathrm{Ci}$; $0.01 \mu \mathrm{g} \mathrm{Pb})$ in $150 \mathrm{mM}$ sodium acetate, $\mathrm{pH} 4.0$. Various incubation times and temperatures were utilized in order to establish optimal conditions for in vitro labeling. Following incubation, milk was cooled to $2-4^{\circ} \mathrm{C}$ then fractionated as described above.

In the third experiment, varying amounts of nonlabeled $\mathrm{PbCl}_{2}$ were added to the in vitro equilibration mix with ${ }^{203} \mathrm{PbCl}_{2}$ to examine effects of increasing $\mathrm{Pb}$ concentrations above trace levels on the distribution of $\mathrm{Pb}$. Rat milk was incubated at $2^{\circ} \mathrm{C}$ for 10 min and subjected to the standard fractionation.

The aim of the fourth experiment was to compare the distribution of ${ }^{203} \mathrm{~Pb}$ in in vitro-labeled bovine milk and infant formula. The milks were incubated with ${ }^{203} \mathrm{PbCl}_{2}$ containing trace quantities of total $\mathrm{Pb}(0.1-0.5 \mu \mathrm{g} / \mathrm{ml}$ of milk). Samples were then fractionated and their $\mathrm{Pb}$ distributions were compared statistically (two-tailed Student's $t$ test using $p<0.05$ as the limit of significance).

Study 2. The goals of this study were to determine the distribution of ${ }^{203} \mathrm{~Pb}$ in lumenal contents from the gastrointestinal tract of infant rats following intragastric administration of rat milk labeled with ${ }^{203} \mathrm{~Pb}$. Because the greatest transfer of $\mathrm{Pb}$ to the infant occurs during late lactation (37), 15- to 16-day-old pups were used in these studies. Two litters of eight pups that had been fasted overnight were intubated intragastrically with $200 \mu \mathrm{l}$ of in vitro-labeled rat milk $(1.8 \mu \mathrm{Ci} ; 0.1 \mu \mathrm{g}$ of $\mathrm{Pb} / \mathrm{ml}$ of milk) and then were returned to their dam to suckle for $2 \mathrm{~h}$. Pups were sacrificed by decapitation, and the stomach and small intestine were removed to a glass plate on ice. The small intestine was divided into proximal and distal halves. The contents were removed by flushing with two volumes of $0.9 \% \mathrm{NaCl}$. Stomach contents were homogenized with a Potter-Elvejham homogenizer for $60 \mathrm{~s}$, and small intestine contents were homogenized with a Polytron (Brinkman Instruments) for $20 \mathrm{~s}$.

The homogenized lumenal contents were fractionated in a manner analogous to that used for milk. Specifically, homogenates were first subjected to low-speed centrifugation $(1700 \times g$ $r_{\max }$ ) for $10 \mathrm{~min}$ in a swinging bucket rotor at $4^{\circ} \mathrm{C}$. This yielded three phases: lipid, aqueous supernatant, and pellet. An aliquot of the aqueous portion was subjected to high-speed centrifugation $\left(72,000 \times g\right.$ at $\left.r_{\max }\right)$ for $45 \mathrm{~min}$ in a swinging bucket rotor at $4^{\circ}$ C. This yielded a supernatant and a pellet.

The total ${ }^{203} \mathrm{~Pb}$ content in each fraction of the homogenized lumenal contents was computed and expressed as the percent distribution per whole homogenate. A separate aliquot of the high-speed supernatant was dialyzed against double-distilled water for $22 \mathrm{~h}$ at $20^{\circ} \mathrm{C}$. Following dialysis, ${ }^{203} \mathrm{~Pb}$ was quantitated in the fluid inside and outside the bag and in the dialysis tubing itself.

\section{RESULTS}

Study 1. Under the conditions used for in vivo labeling of milk, the percentage of the injected dose of ${ }^{203} \mathrm{~Pb}$ found in the milk was $0.141 \pm 0.012 \% / \mathrm{ml}$. Other workers (38) have estimated that at this stage of lactation the daily milk production is $8.3 \mathrm{ml} / \mathrm{pup}$. Using this value, we estimate that the whole litter would have received $9.4 \%$ of the dose/day. This value agrees very well with that of $19.4 \%$ per $48 \mathrm{~h}$ measured by Momcilovic (39) using the same dose of $\mathrm{Pb}$. The actual amount of injected $\mathrm{Pb}$ recovered in whole milk was $0.0028 \pm 0.0003 \mu \mathrm{g} / \mathrm{ml}$, which is considerably less than the value for endogenous $\mathrm{Pb}$ of control rats (i.e. animals not purposefully exposed to $\mathrm{Pb}$ ) raised under similar conditions (38). The percentage of the ${ }^{203} \mathrm{~Pb}$ dose found in the blood of the injected dams was $0.115 \pm 0.013 \% / \mathrm{ml}$, giving actual $\mathrm{Pb}$ concentrations of $0.231 \pm 0.025 \mu \mathrm{g} / \mathrm{dl}$. Here again, comparison with endogenous $\mathrm{Pb}$ in control rats (7.4 $\mu \mathrm{g} \mathrm{Pb} / \mathrm{dl}$ from Ref. 2) shows that we indeed were working with trace levels of ${ }^{203} \mathrm{~Pb}$.

The distribution of ${ }^{203} \mathrm{~Pb}$ in fresh rat milk following administration of ${ }^{203} \mathrm{PbCl}_{2}$ to the dam is seen in the open bars of Figure 1. Low-speed centrifugation showed that less than $5 \%$ of the ${ }^{203} \mathrm{~Pb}$ incorporated into the milk was found in the cream fraction, while more than $90 \%$ was found in the skim milk. On highspeed centrifugation of skim milk, most of the ${ }^{203} \mathrm{~Pb}$ was associated with the casein pellet and very little remained with the whey. Because the in vivo-labelled milk shown in Figure 1 contained only trace levels of total $\mathrm{Pb}$, it was of interest to determine whether the distribution of ${ }^{203} \mathrm{~Pb}$ would be different in milk from $\mathrm{Pb}$-burdened animals. For this purpose four dams were given $0.2 \%$ lead acetate in the drinking water for 9 days before administration of ${ }^{203} \mathrm{~Pb}$. This regime has been reported to result in $\mathrm{Pb}$ concentrations of $1.5-2.5 \mu \mathrm{g} / \mathrm{ml}$ in whole milk (38). The distri-

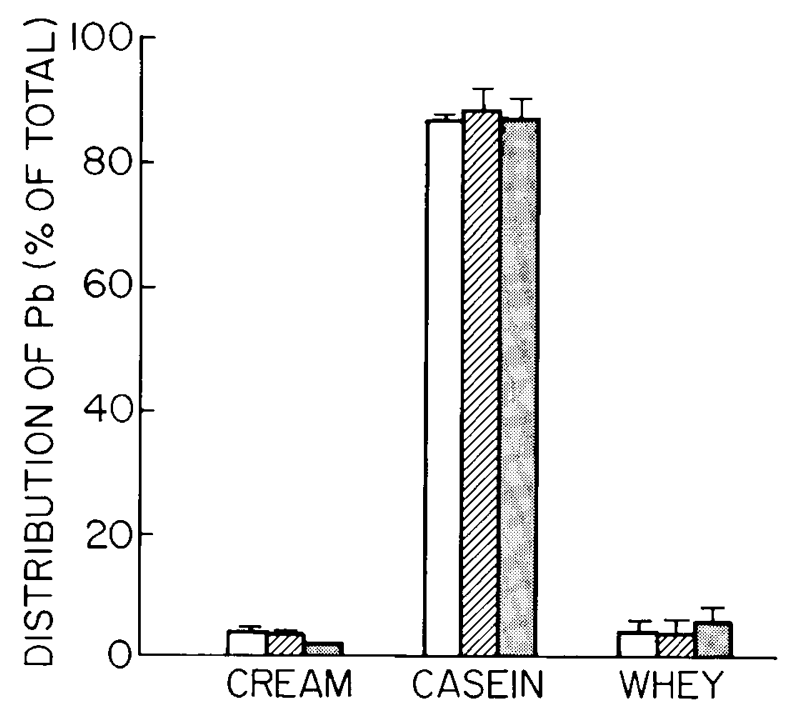

Fig. 1. Distribution of ${ }^{203} \mathrm{~Pb}$ in rat milk. The amount of ${ }^{203} \mathrm{~Pb}$ in each fraction is expressed as a percent of that in whole milk. Data are given as means \pm SEM. Open bars represent milk labelled in vivo $(n=5$ dams); hatched bars represent fresh milk labeled in vitro $(n=4)$; shaded bars represent prior-frozen milk labelled in vitro $(n=4)$. Lack of error bars indicates that the SE was too small to draw. 
bution of ${ }^{203} \mathrm{~Pb}$ in milk from these dams gave values that were not significantly different from those shown in the open bars of Figure 1.

Results of the distribution of ${ }^{203} \mathrm{~Pb}$ in fresh rat milk subjected to in vitro labeling are shown in the hatched bars if Figure 1. As can be seen, the pattern of distribution was virtually the same as for in vivo-labeled milk. Use of prior-frozen milk did not alter the labeling pattern (Fig. 1; shaded bars). Thus for future experiments, milk was obtained and frozen in advance. For the data shown in Figure 1, in vitro labeling was achieved by incubating the milk at $37^{\circ} \mathrm{C}$ for $2 \mathrm{~h}$. Subsequent studies showed that the same distribution of ${ }^{203} \mathrm{~Pb}$ occurred following incubation at $37^{\circ}$ $\mathrm{C}$ for $10 \mathrm{~min}$ and at $2^{\circ} \mathrm{C}$ for either $10 \mathrm{~min}$ or $2 \mathrm{~h}$. Thus, all future studies employed a $10-\mathrm{min}$ incubation at $2^{\circ} \mathrm{C}$.

The data presented in Figure 2 show that the distribution of ${ }^{203} \mathrm{~Pb}$ remained essentially the same over a wide range of total $\mathrm{Pb}$ concentrations. As in Figure 1 , the majority of the ${ }^{203} \mathrm{~Pb}$ was located in the casein fraction with only minor amounts being found in cream and whey. It should be noted that the highest concentration $(75 \mu \mathrm{g} / \mathrm{ml})$ is close to the solubility limit of $\mathrm{PbCl}_{2}$ in the in vitro labeling solution. Higher concentrations could have been studied by increasing the ratio of labeling solution to milk, but this was not deemed necessary because $75 \mu \mathrm{g} / \mathrm{ml}$ is already a much higher concentration than would be expected to occur in milks consumed by either humans or experimental animals (see "Discussion").

The distribution of ${ }^{203} \mathrm{~Pb}$ in bovine milk and infant formula is shown in Figure 3. Statistical comparisons between bovine milk and rat milk (Fig. 1) indicated that there were no significant differences in any milk fractions. For infant formula, the distribution pattern of ${ }^{203} \mathrm{~Pb}$ was similar to that in rat and bovine milk in that most of the ${ }^{203} \mathrm{~Pb}$ was found associated with the casein portion. Direct comparison with bovine milk (Fig. 3) showed infant formula to have significantly more ${ }^{20.3} \mathrm{~Pb}$ in the cream fraction and less in the casein fraction.

Study 2. After intragastric administration of ${ }^{203} \mathrm{~Pb}$-labeled rat milk to rat pups aged 15-16 days, negligible amounts of total ${ }^{203} \mathrm{~Pb}$ were found in the lumenal contents from the proximal small intestine. This precluded further study of these contents (because ${ }^{203} \mathrm{~Pb}$ counts were barely above background levels, even in the unfractionated material). Therefore, only contents from the stomach and the distal small intestine were fractionated. Figure 4 shows that most of the ${ }^{203} \mathrm{~Pb}$ found in the stomach was associated with the low-speed pellet (i.e. the curd). As the labeled

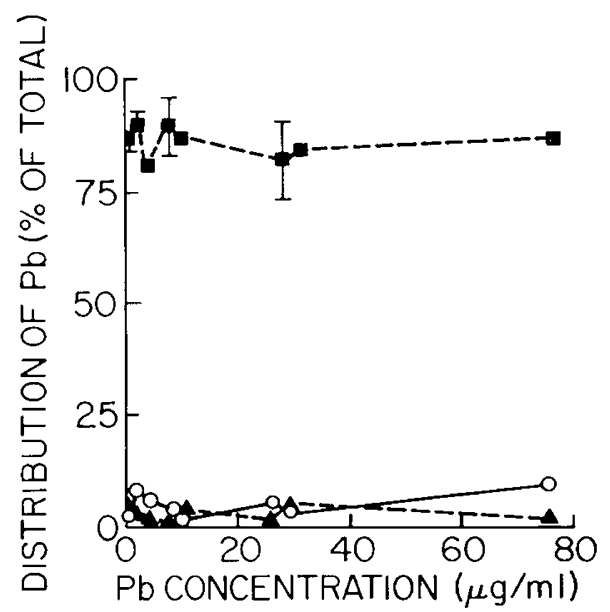

Fig. 2. Distribution of ${ }^{203} \mathrm{~Pb}$ in rat milk following in vitro labeling in the presence of increasing concentrations of total $\mathrm{Pb}$. Milk fractions are as follows: $-\mathbf{-}=$ casein; $\mathbf{\Lambda}--\mathbf{\Lambda}=$ whey; $\mathrm{O}-\mathrm{O}=$ cream. The total added $\mathrm{Pb}$ concentration is given as $\mu \mathrm{g} / \mathrm{ml}$ milk. Results are given as means \pm ranges ( $n=2$ at each concentration of $\mathrm{Pb}$ ). Lack of error bars indicates that ranges were smaller than symbol.

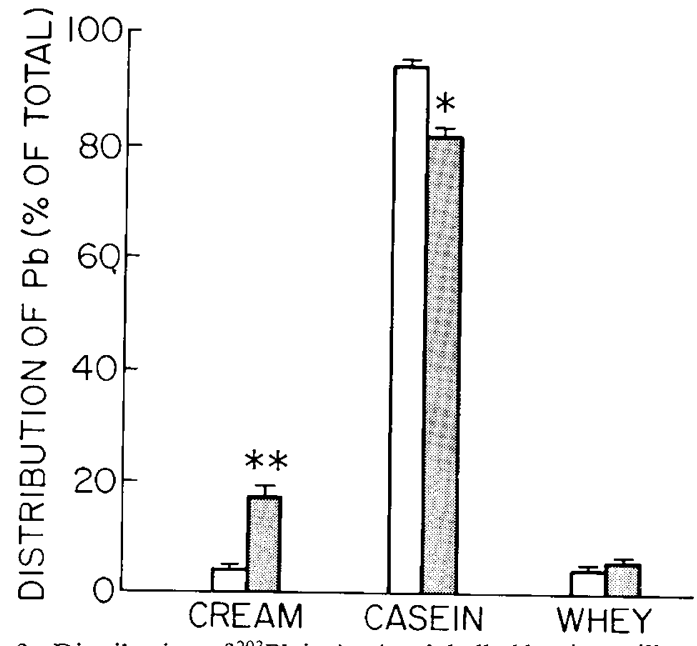

Fig. 3. Distribution of ${ }^{203} \mathrm{~Pb}$ in in vitro-labelled bovine milk and infant formula. For bovine milk ( $\square$ ), $n=4$; for infant formula ( $\square$ ), $n=3$. Statistical significance of differences between these two milks is indicated by asterisks $\left(* *, p<0.001 ;{ }^{*}, p<0.025\right)$. All other details as in Figure 1.

milk moved down the gastrointestinal tract, it was released into the supernatant of the low-speed centrifugation (aqueous portion). Approximately one-third of this ${ }^{203} \mathrm{~Pb}$ (30\% of the wholehomogenate) was precipitable by high-speed centrifugation, indicating that it was still associated with casein micelles. The majority of the ${ }^{203} \mathrm{~Pb}$ in distal contents was found in the highspeed supernatant. Further analysis of the latter fraction was accomplished by dialysis. Results demonstrated that after $22 \mathrm{~h}$, $89.7 \pm 0.7 \%(n=4)$ of the ${ }^{203} \mathrm{~Pb}$ remained inside the bag while only $3.4 \pm 1.8 \%(n=4)$ could be detected in the outside fluid and $7.1 \pm 1.5 \%(n=4)$ was bound to the dialysis tubing. Thus, although substantial amounts of $\mathrm{Pb}$ apparently are released from the casein micelles proper by the time chyme reaches the distal small intestine, the $\mathrm{Pb}$ remains associated with a nondialyzable component of the lumenal fluid.

\section{DISCUSSION}

These studies have shown that the $\mathrm{Pb}$ of rat milk, bovine milk, and milk-based infant formula is associated primarily with the casein micelles. For rat milk, our findings for $\mathrm{Pb}$ are similar to those for $\mathrm{Ca}$, where $77 \%$ was found to be associated with the casein micelles (40). Given the numerous examples wherein $\mathrm{Pb}$ mimics $\mathrm{Ca}$ in biological systems $(41,42)$, such a similarity is not surprising. We have not yet determined whether $\mathrm{Pb}$ actually replaces $\mathrm{Ca}$ or just makes additional similar associations with the casein micelles. For bovine milk, only $41 \%$ of total $\mathrm{Ca}$ is associated with the casein micelles (43), so in this case it is clear that $\mathrm{Pb}$ does not simply equilibrate with $\mathrm{Ca}$. The somewhat lower proportion of $\mathrm{Pb}$ associated with the casein fraction of milkbased infant formula is not surprising, as the protein components of these formulas are now modified so that the casein: whey ratio is 40:60 as compared with 80:20 for bovine milk (44).

Calcium found in the casein micelles of bovine milk has both inorganic and organic components: as entrapped calcium phosphate and as a counterion of the phosphoserine groups of the protein molecules, respectively, the latter predominating (45). Further studies would be necessary to determine whether $\mathrm{Pb}$ preferentially associates with or replaces $\mathrm{Ca}$ in one or the other of these fractions. Based on our studies with material from the lumen of the distal small intestine, we would predict that the $\mathrm{Pb}$ of rat milk is primarily bound to the protein moieties of the casein micelles. The rationale for this prediction is that if it were associated with the inorganic component, it would either remain in a particulate form (and thus appear in the pellet after lowspeed centrifugation) or dissolve (and thus be dialyzable). 


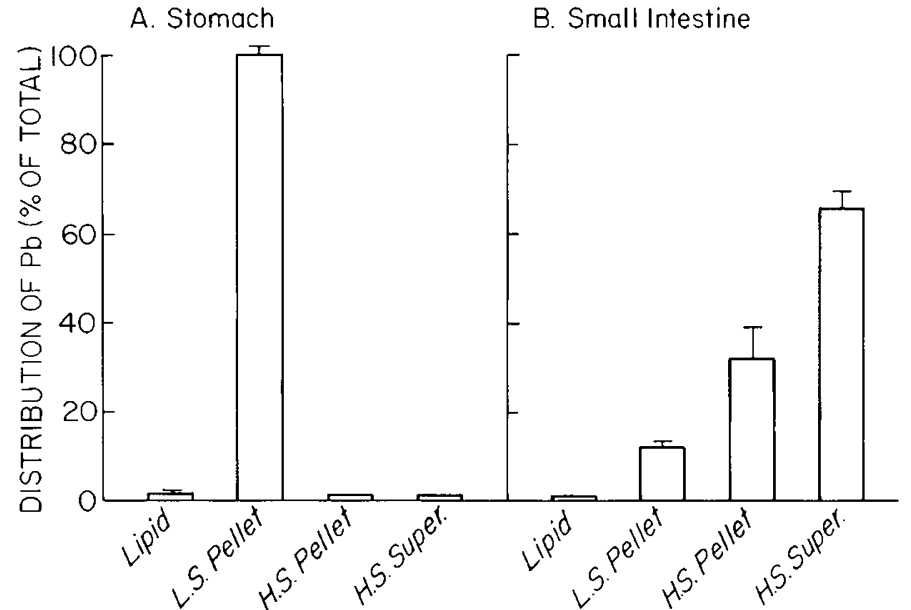

Fig. 4. Distribution of ${ }^{203} \mathrm{~Pb}$ in contents from the gastrointestinal tract of infant rats following intragastric administration of ${ }^{203} \mathrm{~Pb}$-labelled rat milk. $A$ shows data for stomach contents and $B$ shows contents from the distal small intestine. In each panel the bars indicate: lipid fraction, lowspeed pellet, high-speed pellet, and high-speed supernatant, respectively. Results are given as mean \pm SEM $(n=8)$. Lack of error bars indicates that the SEM was too small to draw.

Our finding of an identical distribution of ${ }^{203} \mathrm{~Pb}$ in rat milk labeled in vivo and in vitro suggests that distribution is due to simple chemical interactions rather than being linked in any way to processes involved in milk synthesis. Several essential trace elements, specifically zinc (26), manganese (27), and copper (28), have also been shown to distribute equivalently in milk following extrinsic (i.e. in vitro) labeling. It should be noted, however, that the differential centrifugation method used in these studies and in ours does not allow conclusions as to the chemical details of binding. It is possible, although unlikely, that an equivalent number of different sites are occupied under in vitro as compared with in vivo labeling conditions.

The rapidity of the association between $\mathrm{Pb}$ and casein in vitro $\left(10 \mathrm{~min}\right.$ at 2 or $37^{\circ} \mathrm{C}$ ) suggests that similar associations could occur in the stomachs of animals ingesting other forms of $\mathrm{Pb}$ (e.g. in the drinking water) if milk were consumed either concurrently or soon after. Thus, casein-bound $\mathrm{Pb}$ may be a fairly common form of presentation of ingested $\mathrm{Pb}$ to the small intestine. The high avidity of casein for exogenous $\mathrm{Pb}$ probably explains why canned milk products, including infant formulae, were once found to have substantial concentrations of $\mathrm{Pb}(20$, 46). More recently, the $\mathrm{Pb}$ seams have been removed from cans used for infant formula and thus such products now have very low concentrations of $\mathrm{Pb}$ (Gelardi $\mathrm{RC}$, personal communication).

The fact that $\mathrm{Pb}$ was found associated with the casein fraction of rat milk over a range of concentrations up to $75 \mu \mathrm{g} / \mathrm{ml} \mathrm{milk}$ indicates that in addition to having a high avidity for $\mathrm{Pb}$, casein also has a high capacity for $\mathrm{Pb}$. If the $\mathrm{Pb}$ is simply replacing $\mathrm{Ca}$ (as suggested above), this is not surprising, because rat milk from the same stage of lactation has been found to have a total $\mathrm{Ca}$ content of $976 \mu \mathrm{g} / \mathrm{ml}$ (47). If $77 \%$ of the $\mathrm{Ca}$ of rat milk is associated with casein (40), then the total amount of $\mathrm{Ca}$ found in the casein micelles of rat milk can be calculated as $751 \mu \mathrm{g} / \mathrm{ml}$ milk. Thus, at the highest concentration of $\mathrm{Pb}$ we studied (75 $\mu \mathrm{g} / \mathrm{ml}$ ), we would have been replacing only approximately $10 \%$ of the micellar Ca.

It is important to compare the milk $\mathrm{Pb}$ concentrations used in this study $(0.01-75 \mu \mathrm{g} / \mathrm{ml})$ with those reported as being present in various milks. In experimental animals, even dams purposefully burdened with $\mathrm{Pb}$ have peak $\mathrm{Pb}$ concentrations in the milk ranging from $1.0-2.5 \mu \mathrm{g} / \mathrm{ml}(38,48)$. Thus, in practical terms, our dose-response studies indicate that even at the highest concentration normally occurring in rat milk, $\mathrm{Pb}$ will be associated with the casein micelles. The same can be predicted for bovine milk, as our highest concentration $(75 \mu \mathrm{g} / \mathrm{ml})$ vastly exceeds even the highest concentration $(285 \mu \mathrm{g} /$ liter $)$ which has been reported in recent surveys of bovine milk (18-23).

An original goal of the current project was to study the distribution of ${ }^{203} \mathrm{~Pb}$ in frozen human milk obtained from a local milk bank. Preliminary studies with such milk showed approximately $75 \%$ in the cream, $4 \%$ in the casein, and $1 \%$ in the whey. Because these values were so dramatically different from those obtained with other milks, we decided to check fresh human milk. A sample donated by a lactating female in the laboratory gave the following values for distribution of ${ }^{203} \mathrm{~Pb}$ after in vitro labelling in the standard manner: cream $=3.0 \%$; casein $=85.1 \%$; when $=6.5 \%$ (i.e. very similar to those shown in Fig. 1). When this same milk sample was analyzed after being frozen for various lengths of time, there was a progressive shift out of the casein fraction and into the cream. Thus, we concluded that accurate studies on $\mathrm{Pb}$ distribution in human milk will require freshly collected samples. As we are not in a position to mount such a study, we hope this publication will stimulate others to do so.

Having ascertained that the $\mathrm{Pb}$ of rat milk is predominantly associated with the casein micelles, our next goal was to determine the fate of this $\mathrm{Pb}$ in the gastrointestinal tract of infant rats. Not surprisingly, the stomachs of 15- to 16-day-old pups receiving $\mathrm{Pb}$-labeled milk had $\mathrm{Pb}$ associated with the casein curd. Unfortunately, we were unable to study the contents of the proximal small intestine because of the very low amounts of total ${ }^{203} \mathrm{~Pb}$ found there. It is possible that there are low molecular weight forms of $\mathrm{Pb}$ which are absorbed in this region. In the distal small intestine, most of the $\mathrm{Pb}$ was found in a fraction that was not precipitable by ultracentrifugation (thus, not intact micelles) but was nondialyzable. Further studies are needed to determine whether this nondialyzable component represents solubilized casein molecules. Survival of intact protein molecules of the digestive tract of these animals is to be expected because secretion of gastric acid, pepsinogen, and pancreatic proteases is minimal at this age (32-34). The ileum of suckling rodents has a high capacity for nonspecific pinocytosis $(16,49,50)$, resulting in transfer of macromolecules into lysosomes $(50,51)$. In the case of proteins, the products of lysosomal digestion are then released into the circulation $(52,53)$. There is evidence that $\mathrm{Pb}$ which has had a chance to associate with milk in the stomach of suckling rats subsequently accumulates in ileal tissue $(14,16)$. It has not yet been established whether such $\mathrm{Pb}$ is subsequently released into the circulation or whether it remains in the epithelial cells until they are desquamated. Further studies in this area clearly are warranted.

The findings of this study have important implications for investigations of the bioavailability of $\mathrm{Pb}$ during infancy. To date, absorption studies in experimental animals have all utilized ionic $\mathrm{Pb}(9,14-16,54-56)$. However, for the suckling offspring, the principal source of $\mathrm{Pb}$ would be mother's milk. The data from this study show that $\mathrm{Pb}$ delivered in milk is presented to the small intestine in a bound form. This raises the possibility that ionic $\mathrm{Pb}$ and milk $\mathrm{Pb}$ are absorbed by quite different mechanisms and thus that they may differ markedly in their bioavailability.

Acknowledgments. The authors thank Drs. C. Lau and L. Franklin for their helpful comments on the manuscript.

\section{REFERENCES}

1. Maracek J, Shapiro IM, Burke A, Katz SH, Hediger ML 1983 Low-level lead exposure in childhood influences neuropsychological performance. Arch Environ Health 38:355-359

2. Mahaffey KR 1983 Biotoxicity of lead: influence of various factors. Fed Proc 42:1730-1734

3. Bornschein R, Pearson D, Reiter L 1980 Behavioral effects of moderate lead exposure in children and animal models: Part 1, Clinical studies. CRC Crit Rev Toxicol 8:43-99

4. Bornschein R, Pearson D, Reiter L 1980 Behavioral effects of moderate lead 
exposure in children and animal models: Part 2, Animal studies. CRC Crit Rev Toxicol 8:101-152

5. Chang LW, Wade PR, Pounds JG, Reuhl KR 1980 Prenatal and neonatal toxicology and pathology of heavy metals. Adv Pharmacol Chemother 17:195-231

6. Bithoney WG 1986 Elevated lead levels in children with nonorganic failure to thrive. Pediatrics 78:891-895.

7. Needleman HL, Gunnoe C, Leviton A, Reed R, Peresie H, Maher C, Barrett P 1979 Deficits in psychologic and classroom performance of children with elevated dentine lead levels. N Engl J Med 300:689-695

8. Bhattacharyya MH 1983 Bioavailability of orally administered cadmium and lead to the mother, fetus, and neonate during pregnancy and lactation: an overview. Sci Total Environ 28:327-342

9. Forbes GB, Reina JC 1972 Effect of age on gastrointestinal absorption (Fe, Sr, $\mathrm{Pb}$ ) in the rat. $\mathrm{J}$ Nutr $102: 647-652$

10. Ziegler EE, Edwards BB, Jensen RL, Mahaffey KR, Fomon SJ 1978 Absorption and retention of lead by infants. Pediatr Res 12:29-34

11. Jugo S 1977 Metabolism of toxic heavy metals in growing organisms: a review. Environ Res 13:36-46

12. Kello D, Kostial K 1973 The effect of milk diet on lead metabolism in rats. Environ Res 6:355-360

13. Bell RR, Spickett JT 1981 The influence of milk in the diet on the toxicity of orally ingested lead in rats. Food Cosmet Toxicol 19:429-436

14. Henning SJ, Leeper LL 1984 Duodenal uptake of lead by suckling and weanling rats. Biol Neonate 46:27-35

15. Henning SJ, Leeper LL 1984 Effect of cortisone on intestinal uptake of lead in the suckling rat. Biol Neonate 46:249-253

16. Keller CA, Doherty RA 1980 Correlation between lead retention and intestinal pinocytosis in the suckling mouse. Am J Physiol 239:G114-G122

17. Rabinowitz M, Leviton A, Needleman H 1985 Lead in milk and infant blood: a dose-response model. Arch Environ Health 40:283-286

18. Bruhn JC, Franke AA 1976 Lead and cadmium in California raw milk. J Dairy Sci 59:1711-1717

19. Jonsson H 1976 Determination of lead and cadmium in milk with modern analytical methods. Z Lebensm Unters-Forsch 160:1-10

20. Lamm S, Cole B, Glynn K. Ullmann W 1973 Lead content of milks fed to infants-1971-1972. N Engl J Med 289:574-575

21. Sternowsky HJ, Wessolowski R 1985 Lead and cadmium in breast milk. Arch Toxicol 57:41-45

22. Koops J, Westerbeek D 1978 Determination of lead and cadmium in pasteurized liquid milk by flameless atomic absorption spectrophotometry. Neth Milk Dairy J 32:149-169

23. Marletta GP, Favretto LG 1983 Preliminary investigation on the balance of lead and cadmium content in milk and its by-products. Z Lebensm UntersForsch 176:32-35

24. Duncan JR, Hurley LS 1978 Intestinal absorption of zinc: a role for a zincbinding ligand in milk. Am J Physiol 235:E556-E559

25. Evans GW, Johnson PE 1980 Characterization and quantitation of a zincbinding ligand in human milk. Pediatr Res 14:876-880

26. Sandstrom B, Keen CL, Lonnerdal B 1983 An experimental model for studies of zinc bioavailability from milk and infant formulas using extrinsic labeling. Am $\mathbf{J}$ Clin Nutr 38:420-428

27. Lonnerdal B, Keen CL, Hurley LS 1985 Manganese binding proteins in human and cow's milk. Am J Clin Nutr 41:550-559

28. Lonnerdal B, Bell JG, Keen CL 1985 Copper absorption from human milk, cow's milk and infant formulas using a suckling rat model. Am $J$ Clin Nutr 42:836-844

29. Keen CL, Bell JG, Lonnerdal B 1986 The effect of age on manganese uptake and retention from milk and infant formulas in rats. J Nutr 116:395-402

30. Carmichael D, Christopher J, Hegenauer J, Saltman P 1975 Effect of milk and casein on the absorption of supplemental iron in the mouse and chick. Am
J Clin Nutr 28:487-493

31. Eckhert CD 1985 Isolation of a protein from human milk that enhances zinc absorption in humans. Bioc Biop Res Commun 130:264-269

32. Henning SJ 1981 Postnatal development: coordination of feeding, digestion, and metabolism. Am J Physiol 241:G199-G214

33. Ikezaki M, Johnson LR 1983 Development of sensitivity to different secretagogues in the rat stomach. Am J Physiol 244:G165-G170

34. Henning SJ 1987 Functional development of the gastrointestinal tract. In: Johnson LR (ed) Physiology of the Gastrointestinal Tract. Raven Press, New York, pp 285-300

35. Keen CL, Lonnerdal B, Sloan MV, Hurley LS 1980 Effects of milking procedure on rat milk composition. Physiol Behav 24:613-615

36. Loh TT, Kaldor I 1974 Iron in rat milk: distribution between centrifugally separated phases. J Dairy Sci 57:339-340

37. Kostial K, Momcilovic B 1974 Transport of lead 203 and calcium 47 from mother to offspring. Arch Environ Health 29:28-30

38. Bornschein RL, Fox DA, Michaelson IA 1977 Estimation of daily exposure in neonatal rats receiving lead via dam's milk. Toxicol Appl Pharmacol 40:577587

39. Momcilovic B 1978 The effect of maternal dose on lead retention in suckling rats. Arch Environ Health 33:115-117

40. Blake $\mathrm{HH}$, Henning SJ Absorption and transport of milk calcium by infant rats. Am J Physiol (in press)

41. Fullmer CS, Edelstein S, Wasserman RH 1985 Lead-binding properties of intestinal calcium-binding proteins. J Biol Chem 260:6816-6819

42. Simons TJB 1986 Cellular interactions between lead and calcium. Br Med Bull $42: 431-434$

43. Fransson G-B, Lonnerdal B 1983 Distribution of trace elements and minerals in human and cow's milk. Pediatr Res 17:912-915

44. Hambraeus L, Lonnerdal B, Forsum E, Gebre-Medhin M 1978 Nitrogen and protein components of human milk. Acta Paediatr Scand 67:561-565

45. McMahon DJ, Brown RJ 1984 Composition, structure, and integrity of casein micelles: a review. J Dairy Sci 67:499-512

46. Walker B 1980 Lead content of milk and infant formula. J Food Protec 43:178-179

47. Keen CL, Lonnerdal B, Clegg M, Hurley LS 1981 Developmental changes in composition of rat milk: trace elements, minerals, protein, carbohydrate and fat. J Nutr 111:226-230

48. Lorenzo AV, Gewirtz M, Maher C, Davidowski LI 1977 The equilibration of lead between blood and milk of lactating rabbits. Life Sci 21:1679-1684

49. Clarke RM, Hardy RN 1969 An analysis of the mechanism of cessation of uptake of macromolecular substances by the intestine of the young rat ('closure'). J Physiol 204:127-134

50. Cornell R, Padykula HA 1969 A cytological study of intestinal absorption in the suckling rat. Am J Anat 125:291-316

51. Gonnella PA, Neutra MR 1984 Membrane-bound and fluid-phase macromolecules enter separate prelysosomal compartments in absorptive cells of suckling rat ileum. J Cell Biol 99:909-917

52. Jones RE 1978 Degradation of radioactively labelled protein in the smal intestine of the suckling rat. Biol Neonate 34:286-294

53. Morris B, Morris R 1977 The digestion and transmission of labelled immunoglobulin $G$ by enterocytes of the proximal and distal regions of the small intestine of young rats. J Physiol 273:427-442

54. Pounds JG, Marlar RJ, Allen JR 1978 Metabolism of lead-210 in juvenile and adult Rhesus monkeys (Macaca mulatta). Bull Environ Contam Toxicol 19:684-691

55. Willes RF, Lok E, Treulove JF, Sundaram A 1977 Retention and tissue distribution of ${ }^{210} \mathrm{~Pb}\left(\mathrm{NO}_{3}\right)_{2}$ administered orally to infant and adult monkeys. J Toxicol Environ Health 3:395-406

56. Bushnell PJ, DeLuca HF 1983 The effects of lactose on the absorption and retention of dietary lead. J Nutr 113:365-378 